\title{
Literasi Kemandirian Sikap Mahasiswa Melalui Pembelajaran Entreprenuer Sejarah Pada Mahasiswa Program Studi Pendidikan Sejarah Universitas PGRI Madiun
}

\author{
Soebijantoro*
}

\begin{abstract}
Abstrak
Sikap kemandirian merupakan salah satu pilar keberhasilan seseorang dalam berwirausaha. Seiring dengan ketatnya persaingan kerja, maka perguruan tinggi memiliki tugas untuk mempersiapkan lulusan untuk siap dalam menghadapi persaingan dengan membekali mahasiswa dengan teori dan konsep entrepreneur. Diperlukan literasi entrepreneur kepada mahasiswa melalui proses belajar mengajar entrepreneur yang berupa literasi entrepreneur dalam dimensi ketrampilan, dimensi fungsi serta dimensi media. Melalui literasi tersebut peluang ekonomi akan mudah untuk dipahami oleh mahasiswa. Namun demikian, dalam implementasi kurikulum entrepreneur diperlukan kesadaran akan kontribusi mata kuliah keahlian program studi pendidikan sejarah untuk memperkuat wawasan didalam membaca peluang ekonomi secara kritis.
\end{abstract}

\section{Kata Kunci: Literasi Kemandirian, Sikap, Pembelajaran Entreprenuer Sejarah}

\section{Pendahuluan}

Harus diakui bahwa salah satu permasalahan terbesar dalam dunia pendidikan kita saat ini adalah output yang dihasilkan bukan sebagai opportunity creator melainkan output yang bermental waiting for the opportunity comes. Akibatnya antrian angkatan pencari kerja terus bertambah dan pendidikan seharusnya menyiapkan para siswa bukan sebagai pencari kerja tetapi sebagai pencipta lapangan pekerjaan.

Survey yang dilakukan oleh Litbang Media Group mengatakan bahwa profil tenaga kerja Indonesia dikuasai pekerja, dari 25 juta orang jumlah yang menjadi pengusaha kurang dari seperlima. Salah satu catatan penting dari hasil survey tersebut juga mengatakan bahwa $70 \%$ responden ingin menjadi PNS dan hanya $20 \%$ ingin menjadi pengusaha. Memang Kementerian pendidikan nasional telah mencanangkan program Entrepreneurial Campus dengan tujuan untuk membudayakan berwirausaha di perguruan tinggi. Namun, jumlah entrepreuneur di Indonesia baru tercatat sekitar 1,6\% (atau di bawah standar minimum yakni $2 \%$ ) dari total jumlah penduduk Indonesia 240 juta penduduk.

Sementara semua negara maju saat ini mencatat memiliki entrepreneur berbanding dengan jumlah penduduknya adalah di atas $5 \%$. Terkait dengan hal itu, Michael Stewart (2015:3) mengatakan bahwa Perguruan tinggi merupakan salah satu lembaga yang ikut pula bertanggung jawab terhadap upaya mempersiapkan 
mahasiswa untuk membekali sikap kemandirian dalam menghadapi era persaingan global. Bahkan perguruan tinggi harus ikut bertanggung jawab dalam memberi jalan bagi para lulusan untuk dapat mengembangkan karir melalui kesempatan dunia kerja melalui penyiapan dan pembekalan kepada lulusan dalam dunia kerja.

Dalam konteks tersebut diatas, penulis telah melakukan penelitian awal yang menunjukkan bahwa responden dari lulusan program studi pendidikan sejarah Universitas PGRI Madiun sejumlah 80\% mengatakan bahwa mata kuliah entreprenuer telah membuka pemahaman bahwa setelah lulus mereka tidak harus menjadi pendidik atau guru. Hal itu berakibat masa tunggu untuk bekerja rata rata 1,5 bulan. Namun disisi lain data alumni menunjukkan bahwa hanya 0,5\% yang benar benar terjun sebagai seorang entreprenuer.

Dari kajian awal terungkap bahwa salah satu kendala yang dihadapi mahasiswa dalam berwirausaha adalah ketidaksiapan mental serta lemahnya sikap kemandirian dalam berwirausaha. Seperti yang disampaikan oleh Ciputra (2017: 12) bahwa diperlukan sikap mental kemandirian apabila seseorang ingin menjadi seorang entreprenuer. Sebuah sikap yang dibutuhkan ketika akan mengambil sebuah peluang dan siap menghadapi resiko dari peluang itu. Dari kajian awal itu pula menunjukkan bahwa dalam proses belajar mengajar entreprenuer dijumpai keterbatasan ketersediaan bahan ajar entreprenuer sejarah yang disusun berbasis kebutuhan mahasiswa dan stakeholder.

Hal ini sangat mendesak sebab dengan hadirnya bahan ajar tersebut dapat memberikan wawasan kepada mahasiswa tidak hanya teori dan konsep wirausaha namun berisikan pula pelatihan pelatihan bagaimana mahasiswa menyusun program kewirausahaan berbasis sejarah. Sehingga problematika pengangguran sarjana di Indonesia dapat dihadapi secara bijak.

\section{Literasi Kemandirian Mahasiswa Dalam Berwirausaha}

Kemandirian merupakan salah satu aspek yang dibutuhkan ketika seseorang berkeinginan untuk mengembangkan kemampuan berwirausaha. Fatimah (2006:12) mengatakan bahwa kemandirian berarti hal atau keadaan dimana seseorang harus dapat berdiri sendiri tanpa bergantung pada orang lain. Terkait dengan hal itu, menurut Parker (dalam Ali, 2005: 30), kemandirian juga dapat diartikan sebagai suatu kondisi seseorang yang tidak bergantung kepada otoritas dan tidak membutuhkan arahan secara penuh.

Sedangkan Brawer (dalam Havinghurts, 1993) mengatakan bahwa kemandirian merupakan perilaku yang terdapat pada seseorang yang timbul karena 
dorongan dari dalam dirinya sendiri, bukan karena pengaruh orang lain. Hal senada disampaikan oleh Parker (2005: 227) bahwa kemandirian (self reliance) adalah kemampuan untuk mengelola semua yang dimiliki, tahu bagaimana mengelola waktu, berjalan dan berpikir secara mandiri disertai dengan kemampuan mengambil resiko dan memecahkan masalah.

Dari penjelasan tersebut ditegaskan bahwa individu yang mandiri mencoba untuk tidak membutuhkan petunjuk yang detail dan terus menerus tentang bagaimana mencapai produk akhir namun akanbersandar pada kemampuan diri sendiri dalam arti dengan kemandirian seseorang dalam melakukan sesuatu tidak memiliki keragu-raguan dalam menetapkan tujuan dan tidak dibatasi oleh kekuatan akan kegagalan.

Dari beberapa pengertian di atas maka sikap kemandirin merupakan kemampuan seseorang dalam melepaskan diri dari ketergantungan pada orang lain dan mampu mengambil keputusan dan berkomitmen pada keputusan yang diambil, serta mampu bertingkah laku sesuai nilai yang diyakini dan berlaku pada lingkungan.

Steinberg (dalam Yusuf, 2001:15) mengatakan bahwa terdapat tiga aspek dalam kemandirian yang harus dibangun kepada mahasiswa yaitu pertama kemandirian emosi. Kemandirian ini merujuk kepada pengertian yang dikembangkan oleh anak mengenai individuasi dan melepaskan diri atas ketergantungan mereka dalam pemenuhan kebutuhan-kebutuhan dasar dari orang tua mereka.

Secara operasional aspek kemandirian ini terdiri dari beberapa indikator seperti: 1) memandang orang tua apa adanya, 2) melihat orang tua sebagai orang dewasa lainnya, 3) dapat mengandalkan dirinya sendiri dari pada bergantung pada orang tuanya, dan individuation artinya remaja memiliki pribadi yang berbeda dengan orang tuanya. Terkait dengan penjelasan tersebut, maka dalam penelitian ini lebih menekankan kepada sikap kemandirian dalam konteks kemandirian perilaku dan nilai.

Kedua adalah kemandirian perilaku adalah kemandirian yang merujuk kepada kemampuan seseorang membuat keputusan secara bebas dan konsekuen atas keputusannya itu. Sedangkan yang ketiga adalah kemandirian nilai pada seeorang yang merujuk kepada kemampuan untuk memaknai seperangkat prinsip tentang benar dan salah, serta penting dan tidak penting. Dengan demikian diharapkan mahasiswa diharapkan dapat menunjukkan ciri khas yaitu:

1. selalu berorientasi pada kualitas dan prestasi.

2. mewujudkan aktualisasi dirinya dengan kerja keras dan memfokuskan diri.

3. memberikan sikap dan tindakan terbaik terhadap apa yang sedang dilakukan 
4. bersinergi untuk berkontribusi dalam mencapai tujuan.

Terwujudnya sikap kemandirian dikalangan mahasiswa program studi pendidikan sejarah tentunya harus terwujud dalam sebuah proses literasi yang terintegrasi dalam pembelajaran entrepreneur. Dalam konteks tersebut penulis melihat terdapat tigas dimensi literasi yang dapat dilakukan yaitu:

1) dimensi ketrampilan meliputi membaca, menulis, menghitung, dan berbicara. Literasi ini bersifat individu dilihat dari tampaknya kegiatan membaca, menulis, menghitung, dan berbicara. Dalam tradisi orang barat, ada tiga ketrampilan yang tergambar dalam $3 \mathrm{R}$ yaitureading, writing, dan arithmetic.

2) Dimensi fungsi, yaitu literasi guna memecahkan persoalan, mendapatkan pekerjaan, mencapai tujuan, mengembangkan pengetahuan, dan mengembangkan potensi diri serta

3) Dimensi media, (teks, cetak, visual, digital) sesuai dengan perkembangan teknologi yang sangat pesat, begitu juga teknologi dalam media literasi. Penulis melihat bahwa proses tersebut tidak hanya terwujud dalam pencapaian kognisi mahasiswa dalam proses belajar mengajar saja akan tetapi terimplmentasi pula.

Dari hasil penelitian awal terungkap bahwa mahasiswa sangat membutuhkan referensi yang berbasis keterampilan fungsi melalui pelatihan sebagai calon wirausaha serta referensi yang disusun berdasarkan kebutuhan mahasiswa. Khusus dalam pembelajaran kewirausahaan pada mahasiswa program studi pendidikan sejaeah, terungkap bahwa sampai saat ini belum tersedia bahan ajar entrepreneur berbasis sejarah, artinya referensi referensi yang dapat dipergunakan oleh mahasiswa sejarah sebagai panduan untuk terjun dibidang kewirausahaan melalui keterampilan pengetahuan sejarah khususnya dibidang pariwisata.

Literasi berdimensi fungsi inilah yang akan diimplementasikan melalui kurikulum KKNI bagi mahasiswa program studi pendidikan sejarah UNIPMA mengingat potensi pariwisata di Kota dan Kabupaten Madiun belum dinaksimalkan oleh para pemangku kepentingan. Dalam kajian penulis mahasiswa pendidikan sejarah UNIPMA akan lebih mudah terlibat dalam proses literasi kewirausahaan ini karena bekal pengetahuan tentang teori dan konsep sosiologi, antropologi yang sangat dibutuhkan dalam upaya menggali peluang pemberdayaan ekonomi masyarakat melalui pariwisata.

Disamping itu penulis juga melihat bahwa di era digital saat ini yang mulai merambah dalam pelakasanaan proses belajar mengajar di perguruan tinggi, maka perlu kiranya hadir bahan ajar yang dapat diakses oleh mahasiswa sehingga materi akan tersaji dengan menarik dengan tingkat 
keterbacaan mahasiswa yang baik serta mudah diakses secara efektif dalam keterbatasan alokasi waktu perkuliahan.

\section{Pembelajaran Entreprenuer Sejarah \\ Suatu Harapan dan Tantangan}

Dalam Undang-Undang No. 20 Tahun 2003 Tentang Sistem Pendidikan Nasional pasal 1 ayat 20 dinyatakan bahwa pembelajaran adalah proses interaksi peserta didik dengan pendidik dan sumber belajar pada suatu lingkungan belajar. Hal ini berarti dalam sebuah pembelajaran terdapat kegiatan yang dirancang untuk membantu seseorang mempelajari suatu kemampuan dan nilai yang baru.

Dengan demikian dapat ditarik kesimpulan bahwa Pembelajaran adalah usaha sadar dari pendidik untuk membuat siswa belajar sehingga terjadinya perubahan tingkah laku pada diri siswa yang belajar, dimana perubahan itu dengan didapatkannya kemampuan baru yang berlaku dalam waktu yang relative lama dan karena adanya usaha.

Menurut Thomas Zimmerer (2008: 15) dikatakan bahwa entrepreneur (kewirausahaan) adalah penerapan kreativitas dan keinovasian untuk memecahkan permasalahan dan upaya memanfaatkan peluang-peluang yang dihadapi orang setiap hari .Terkait dengan hal itu, Andrew J. Dubrin (2008: 23) mengatakan bahwa entrepreneur adalah seseorang yang mendirikan dan menjalankan sebuah usaha yang inovatif. Peterdan Shepherd (2008: 65) memberikan definisi entrepreneurship sebagai proses penciptaan kekayaan incrementalyaitu kekayaan yang diperoleh melalui kemampuan dalam berinovasi dalam memanfaatkan sumberdaya serta memahami segala resiko yang harus diterima dalam proses tersebut.

Dari penjelasan tersebut diatas, nampak bahwa istilah entrepreneur (kewirausahaan) pada dasarnya merupakan suatu disiplin ilmu yang mempelajari tentang nilai, kemampuan (ability) dan perilaku seseorang dalam menghadapi tantangan hidup untuk memperoleh peluang dengan berbagai risiko yang mungkin dihadapinya. Hal ini berarti bahwa entrepreneurship adalah segala hal yang berkaitan dengan sikap, tindakan dan proses yang dilakukan oleh para entrepreneur dalam merintis, menjalankan dan mengembangkan usaha mereka.

Dengan demikian, entrepreneurship merupakan gabungan dari kreativitas, inovasi dan keberanian menghadapi resiko yang dilakukan dengan cara kerja keras untuk membentuk dan memelihara usaha baru. Dari pandangan para ahli dapat disimpulkan bahwa entrepreneurship adalah kemampuan dalam berfikir kreatif dan berperilaku inovatif yang dijadikan sebagai dasar, sumber daya, tenaga penggerak, tujuan siasat, kiat dan proses dalam menghadapi tantangan hidup. 
Dari pengertian entrepreneur dan pembelajaran tersebut diatas, maka pembelajaran entreprenuer dapat diartikan sebagai sebuah proses aktifitas yang secara sengaja dilakukan dalam sebuah lingkungan yang memungkinkan peserta didik memiliki kemampuan dalam berfikir kreatif dan berperilaku inovatif yang dijadikan sebagai dasar, sumber daya dan tenaga penggerak serta strategi sebagai sebuah perilaku yang diharapkan dapat menghasilkan respons peserta didik dalam menghadapi tantangan hidup.

Dengan demikian, dalam konteks pembelajaran pada program studi pendidikan sejarah dapat dijelaskan bahwa sesuai dengan visi misi program studi maka mata kuliah entrepreneur diharapkan dapat membekali kemampuan inteprenuership lulusan ketika kembali ke masyarakat melalui kemampuan atau kompetensi seorang pendidik dan peneliti sejarah.

Harapan yang dilakukan dalam redesain kurikulum di UNIPMA adalah berangkat dari pendapat Peter Drucher bahwa perlu diciptakannya tindakan kreatif yang dapat membangun value untuk menangkap peluang dari sumberdaya yang ada. (Peter Drucher, 2013: Dalam http://www.dokterbisnis.net/2013/10/02). Menurut (Bechard, J.P. dan Gregoire, D., 2005: 44) yang dimaksud dengan tindakan kreatif adalah tindakan yang mampu memanfaatkan peluang potensi sumberdaya sejarah melalui kemampuan menarasikan, memvisualisasikan dan diberdayakan dalam berwirausaha.Berangkat dari latar belakang masalah tentang keterserapan yang sangat terbatas, maka entreprenuer diharapkan dapat membekali kompetensi mahasiswa dibidang wirausaha khususnya pada obyek obyek sejarah.

Implementasi entrepenuer diawali dengan penetapan capaian Pembelajaran Utama yaitu mampu melaksanakan usaha secara mandiri di luar bidang kependidikan dengan bekal kewirausahaan sedangkan capaian pembelajaran khusus adalah mampu berinovatif-kreatif dalam usaha pariwisata budaya sejarah. Oleh karena basis bidang ilmu mahasiswa adalah kependidikan, maka langkah strategis pertama yang ditetapkan oleh program studi adalah memberdayakan kompetensi mahasiswa untuk mampun membaca peta sejarah.

Kemampuan ini diawali dari pelatihan maping sejarah lokal yang ada di lingkungan tempat tinggal mahasiswa. Mapping dapat dilakukan dari skala yang kecil mulai dari desa atau kecamatan hingga skala besar yaitu di tingkat kabupaten atau propinsi. Kemampuan dalam membaca maping sejarah berangkat dari kemampuan untuk menentukan obyektifitas kesejarahan suatu obyek sejarah. Hasil yang diperoleh dari maping sejarah ini dapat disebut sebagai aset informasi sejarah. Dalam praktik awal mahasiswa pendidikan sejarah UNIPMA dibekali oleh peta sejarah yang 
diaplikasikan di wilayah kota dan kabupaten Madiun. Hal itu seperti yang dikatakan oleh (Slamet M., 1992: 21) bahwa maping sejarah tanpa disadari akan memberi keuntungan ganda bagi mahasiswa yaitu dapat merelevansikan sejarah lokal dalam konteks nasional bahkan global.

Oleh sebab itu potensi sejarah yang melimpah akan lebih bermanfaat apabila digali bersama kemampuan dibidang enterprenuer. Materi enterprenuer yang diberikan kepada mahasiswa pendidikan sejarah meliputi pentingnya bisnis historiopreneur dan keputusan menjadi pelaku bisnis berbasiskan budaya sejarah serta kreativitas dan inovasi bisnis historiopreneur budaya sejarah. Oleh karena itu, dibutuhkan kreativitas dan inovasi bisnis, maka mahasiswa dibekali materi konsep pemasaran, strategi dan taktik pemasaran serta konsep bauran pemasaran.

Hal ini sangat penting mengingat dunia enterprenuer sangat dekat dengan berbagai resiko. Oleh sebab itu, mahasiswa dibekali pula dengan materi konsep resiko dan manajemen resiko, serta identifikasi resiko bisnis historiopreneur budaya sejarah. Secara teoritis, implementasi akan terwujud apabila proses pembelajaran yang diharapkan dapat berjalan dengan baik, namun demikian tantangan yang harus dihadapi oleh pengambil kebijakan kurikulum entrepreneur di perguruan tinggi adalah terwujudnya langkah sinergi antara materi pembelajaran entrepreneur dengan materi perkuliahan pendukung entrepreneur pada program studi pendidikan sejarah.

Fakta di lapangan menunjukkan bahwa seolah-olah mata kuliah yang diberikan di program studi pendidikan sejarah berdiri sendiri guna membekali mahasiswa sebagai calon pendidik untuk menguasai bidang yang terkait dengan pendidikan dan pengajaran. Menurut penulis seharusnya semua mata kuliah khususnya mata kuliah keahlian memberikan kontribusi informasi peluang ekonomi yang dapat diambil dan dikembangkan oleh mahasiswa apabila ingin berwirausaha.

\section{Penutup}

\section{Kesimpulan}

Dari uraian tersebut diatas maka dapat diambil sebuah kesimpulan bahwa sikap kemandirian mahasiswa pendidikan sejarah yang dibutuhkan sebagai salah satu pilar keberhasilan dalam berwirausaha harus dicapai melalui literasi entrepreneur dalam sebuah proses belajar mengajar sejarah secara terintegrasi dan mengerucut guna memenuhi visi dan misi universitas yang juga ingin mencetak lulusan yang siap sebagai seorang entrepreneur. Adapun literasi entrepreneur dapat dicapai melalui dimensi keterampilan, dimensi fungsi serta dimensi media. 


\section{Daftar Pustaka}

Andrew J. DuBrin. 2008. Essentials of Management: South Western Educational Publishing

Avenia. 2014. Pandangan Pelaku Pendidikan di Universitas Terhadap Pembentukan Masyarakat Ekonomi Asean. Berita Ekonomi. FE Unpar:Bandung.

Bechard, J.P. dan Gregoire, D. 2005. Intrepreneurship education research revisited: The case of higher education, Academy of Management, Learning \& Education. Monas University.

Ciputra. 2013. Entreprenuership Education WithoutBoundaries.http://ciputrauc eo.net/blog/2013/9/7/identifikasijenis-entreprenuer

Dirjen Pendidikan Tinggi Kemendiknas. 2010. Kerangka Acuan Pendidikan Karakter: Jakarta.

Fatimah. 2006. Psikologi Perkembangan. Bandung: CV Pustaka Jaya.

Gualdron Morales dalam Nebosja Zakic, Milan Stamatovic, Stevovic. 2012. Necessity of entreprenuership education: $A$ research among entreprenuers and potential entreperenuer in Serbia dalamAfrican Journal of Business Management. No.6.9. Maret 7, 2012: 3173-3180.

Michael Lounsbury, Mary Ann Glynn. 2001. Cultural Entreprenuership Stories, legitimacy and acquisition of Resources. dalam Strategic Management Journal: Juni/Juli 2001, 22, 6/7, ProQuest Health Management.

Michael Stewart. 2015. Why University need an entreprenuersial Spirit by the World Economic Forum.(Online). https://www.weforum.org/agenda/ 2015/05/ why-universities-needan-entrepreneurial-spirit/
Michael P Pieters, Dean A. Sheperd. 2008.Entreprenuership. Boston: Mc Graw Hill.

Parker. 2005. Psikologi Perkembangan Remaja. Jakarta: Grasindo.

Slamet Mulyono. 1999. Sejarah Lokal. Bandung: Bumi Aksara.

Tim Pusat Kurikulum Pengembangan Pendidikan Entreprenuer. 2010. Bahan Pelatihan Penguatan Metodologi Pembelajaran Entreprenuer Berdasarlan Nilai Budaya Untuk Membentuk Daya Saing dan Kualitas Bangsa. Jakarta: Balitbang Depdiknas.

Thomas Zimmer. 2008. Kewirausahaan dan Management Usaha Kecil. Jakarta: Salemba Empat.

Yusuf.2001. Psikologi Perkembangan Anak dan Remaja. Bandung: PT Remaja Rosia. 